\title{
On Eugene Garfield and Indexing: A Biographical Review
}

\author{
Ozturk Onur ${ }^{1}$, Dost Betul Ozcan ${ }^{2}$, Dost Emrah ${ }^{3}$, \\ Yalcin Bektas Murat ${ }^{4}$, Unal Mustafa ${ }^{4}$ \\ Email address: \\ dr.onurozturk@yahoo.com (O. Onur)
}

Abstract: Eugene Garfield was born in 1925, United States. He is a world-wide known American scientist. He is also one of the founders of bibliometrics and scientometrics, an art lover, a multilinguist, an entrepreneur, a musician and a prolific author. Garfield is mostly known around the world for ISI. Thanks to ISI, created by Garfield, researchers from all disciplines have been benefiting from a more systematic, faster, objective, interdisciplinary and extensive system while carrying out their researches and this index has enabled them to track down the origins of a scientific idea and led to creation of other information retrieval algorithms.

Keywords: Eugene Garfield, ISI, Indexing

So much has been written about Eugene Garfield and a lot of interviews have been done with him. His works are of big importance for the science world and researchers. Therefore, there is a great interest in his works.

Eugene "Gene" Garfield was born in September 16, 1925 in New York City, New York, United States (1). Garlfield is a world-wide known scientist. He has a multi-faceted personality, so engages in several fields. $\mathrm{He}$ is an American scientist, one of the founders of bibliometrics and scientometrics, an art lover, a multilinguist, an entrepreneur, a musician and a prolific author (2). However, he says that he calls himself an information scientist (3).

We can see the multifaceted personality of Garfield also in his education life. Garfield graduated from Department of Chemistry at Columbia University in 1949 and received his M.S. Library Science in 1954. Later, he received his Ph.D. degree in Structural Linguistics at the University of Pennsylvania in 1961 (1).

Garfield reflected his educational background on his work and worked in several fields. During the early 1950s he worked on the Welch Library indexing project at the John Hopkins University School of Medicine. In this project, he sorted and indexed documents from medical papers and journals. Benefiting from his graduate degree in library sciences, he went into business as a "documentation consultant". At that time, he was also working on his doctorate in structural linguistics. In 1960, he founded the Institute for Scientific Information (ISI), his most famous contribution to the science world. Subscriptions of ISI were sold to Science Citation Index and by time it started to include the Social Sciences Citation Index (SSCI) and the Arts \& Humanities Citation Index (A\&HCI). These databases are now of great importance for the science world. They form the foundation of the online research tool the "Web of Knowledge" (4). 
Furthermore, Garfield likes sharing, so he tried to share his knowledge and experience with students. He worked as an adjunct professor in the computer and information science at the University of Pennsylvania. He also wanted to share his knowledge and experience with other researchers and people interested in science. In 1986 Garfield launched a magazine for science researchers called The Scientist. His Essays of an Information Scientist (1977) collects columns published as Current Comments between 1962 and 1976 (4). For a long time, he has contributed every week an essay as the editorial of Current Contents (CC) (2). He stated that there was no problem of shortage of topics to be covered in $\mathrm{CC}$ and its scope got larger gradually and thanks to its content including more personal topics, it was beneficial in distracting researchers from the scientific topics (5).

Garfield has also published numerous books and articles mainly on scientific information retrieval and related topics. His articles varied in topics and were published in various journals. He published articles on several topics including cultural and economic imperialism of science, science for the sake of science, obliteration phenomenon in science, gatekeepers in science, keeping up with science, identification of paradigms in science, unanswered questions of science, negative science, high impact science, French science, science on television, public confidence in science, social impact of science, etc. His works on varied topics were published in varied journals, which are prestigious in their fields. These journals included like Nature, New Scientist, Science, Science 80, Science Digest, Omni, Scientific American, Science News, and Discovery (2).

He also wrote biographies of several people such as his parents, brother, famous people and Nobel-prize winners. Chauncey D. Leake, Jacob Gershon-Cohen, A. E. Cawkell, Herbert S. White, Morton V. Mallin, Richard M. Harris, Samuel Lazerow and Marvin Shroeder are just some of the people whose biographies were written by Garfield (2).

On the other hand, he said in an interview that he wanted to publish a constantly current dictionary of science and explained the reason for this:

What could be a better source of new terms than the ISI database? There is constant input of new terminology. The nomenclature from indexing services is not systematically being exploited to compile dictionaries. Libraries spend a lot of energy compiling thesauri. Most of those terms eventually do get into dictionaries, but it could take many years (6).

He has also held different professional positions such as Staff member, Welch Machine Indexing Project, Johns Hopkins University in 1951-1953; Chairman Emeritus, Institute for Scientific Information from 1993-present; President, The Scientist LLC from 2001-present. Moreover, he has taken roles in different scientific and professional associations such as American Academy for Arts \& Sciences, American Philosophical Society, Philadelphia, PA. - Member and Society for Social Studies of Science. On the other hand, he took part in editorial board membership in different places such as Annual Reviews, Inc., Board of Directors, Rockefeller University Council and Research! America (1).

He has received numerous awards such as Award of Merit,
American Society of Information Science in 1975; American Society for Information Science Book Award for Best Information Science Book of 1977 in 1978 and Avenue of Technology Award, Philadelphia, PA in 1999. And he received honors such as Honorary Fellow, Medical Libraries Association in 1993; Honorary Membership in the Russian Academy of Sciences, Vladivostok, Russia in 1997 and Honorary Degree from Real Academia de Medicina Del Distrito de Granada (Andalucia Oriental) Spain in 2007 (1).

Garfield has made a lot of contributions to science, but the most important one is SCI. Therefore, it is important to know about the importance of SCI to know the importance of Garlfield for science. Though it was devised by the Chemist Garfield, SCI helped scientists from all sciences. Both Garfield and others wrote several articles on this tool.

Although studies on counting sources of scientific works and compiling them in an order and rating and classifying scientific journals dates back to the beginning of $1900 \mathrm{~s}$, Garfield focused on machine generated indexes in the mid1950 's and early 1960's and carried out the most important of these studies (7). He published a paper titled "Citation Indexes for Science: A New Dimension in Documentation through Association of Ideas.", which was innovative in the field (8).Three years later, he established "Institute for Scientific Information (ISI)"in 1958. In the beginning, it was an index and work of reference analyzing chemistry only. Later, it started to comprise all other disciplines (9).

In 1992, ISI was purchased by Thomson Publishing Group and continued to be a world-wide known reference source of information. This index started by Garfield and continued by Thomson-ISI is called Science Citation Index (SCI). This index analyses sources of approximately 4000 international journals and data obtained from this index has been published regularly since 1963 (9). Moreover, there is another important concept for this index. It is called "Impact Factor". Impact factor is defined as "The average number of times articles from the journal published in the past two years have been cited in the JCR year" (10). Impact factors of journals have been published under the name "Journal Citation Reports (JCR)" since 1975 (9).

Garfield thinks that it is important to be aware and make use of indexes in the science world. He explained this as following:

I find it very frustrating that so many scientists are ignorant of what they could do with information retrieval systems. I think it is important not only to be literatureminded, but to develop citation consciousness. I'm not sure how you teach this. It requires indoctrination by informed mentors (6).

In his statement, he pointed out the importance of scientists' awareness about the indexes to be used in their researches. Though he says he isn't sure about how to raise awareness about them, he touches on an important matter to be taken account in the use of indexes.

Thanks to this index devised by Garfield, subjective human judgement problems could be eliminated by enabling 
impact factor and incorporation of information in to the indexes sped up. This way, objectiveness and faster access to information were provided (7). Moreover, Garfield's work led to the development of several information retrieval algorithms, like HITS and Pagerank, which both use the structured citation between websites through hyperlinks (1).On the other hand, as Garfield said: "Traditionally, indexing was done within each scientific discipline", "Science Citation Index ${ }^{\circledR}$, which is now available via Web of Science, the core database in ISI Web of Knowledge SM, integrated the data with an interdisciplinary approach. Therefore, researchers in one field often create work relevant to researchers in another." Furthermore, SCI is useful in tracking down the origin of a scientific idea (8).

We can say that Eugene Garfield has created works in different fields based on his multifaceted personality and education. And his hard work has been awarded and made him a world-wide known scientist and most importantly creator of the well-known index: ISI. Thanks to this work of Garfield, researchers from all disciplines have been benefiting from a more systematic, faster, objective, interdisciplinary and extensive system while carrying out their researches and this index has enabled them to track down the origins of a scientific idea and led to creation of other information retrieval algorithms.

P.S.: We would like to thank Mr Garfield kindly for giving permission to write his biography by writing a response to our e-mail on the $9^{\text {th }}$ April 2014.

\section{References}

[1] http://www.garfield.library.upenn.edu/ 05.01.2015.

[2] Eugene Garfield-Glimpses of his writings. B. K. Sen. J Scientometric Res. | Jan-Apr 2014 | Vol 3 | Issue 1.

[3] BukuMaklumat. Information Booklet. Malaysian Citation Centre. 2012.

[4] http://www.infoplease.com/biography/var/eugenegarfield.html 05.01.2015.

[5] Interview with Eugene Garfield. SvetlaBaykoucheva. Chemical Information Bulletin, Fall 2006, Vol. 58, No. 2, p. 7 9.

[6] Deeds and Dreams of Eugene Garfield. Chemical Intelligencer, p.26-31, October 1999.

[7] https://courses.washington.edu/infx598/win12/GarfieldCameo .htm 02.01.2015.

[8] http://wokinfo.com/essays/50-years-citation-indexing/ 15.01.2015.

[9] Ulusal Atif Dizini Ve Dergilerimizin Etki Faktörleri. Sercan Özyurt. Saglik Bilimlerinde Sureli Yayincilik - 2007.

[10] http://adminapps.webofknowledge.com/JCR/help/h_impfact.htm 03.10.2014. 